\title{
Effects of low-oxygen conditions on embryo growth in the painted turtle, Chrysemys picta
}

Cordero, Gerardo A.; Karnatz, Matthew L.; Svendsen, Jon Christian; Gangloff, Eric J.

Published in:

Integrative Zoology

Link to article, DOI:

10.1111/1749-4877.12206

Publication date:

2017

Document Version

Peer reviewed version

Link back to DTU Orbit

Citation (APA):

Cordero, G. A., Karnatz, M. L., Svendsen, J. C., \& Gangloff, E. J. (2017). Effects of low-oxygen conditions on embryo growth in the painted turtle, Chrysemys picta. Integrative Zoology, 12(2), 148-156.

https://doi.org/10.1111/1749-4877.12206

\section{General rights}

Copyright and moral rights for the publications made accessible in the public portal are retained by the authors and/or other copyright owners and it is a condition of accessing publications that users recognise and abide by the legal requirements associated with these rights.

- Users may download and print one copy of any publication from the public portal for the purpose of private study or research.

- You may not further distribute the material or use it for any profit-making activity or commercial gain

- You may freely distribute the URL identifying the publication in the public portal 


\title{
SHORT COMMUNICATION
}

Effects of low-oxygen conditions on embryo growth in the painted turtle, Chrysemys picta

\author{
Gerardo A. Cordero ${ }^{1, *}$, Matthew L. Karnatz ${ }^{1}$, Jon C. Svendsen ${ }^{2,3}$, Eric J. Gangloff ${ }^{1}$
}

1 Department of Ecology, Evolution, and Organismal Biology, Iowa State University, Ames, Iowa 50011 USA

2 Technical University of Denmark, National Institute of Aquatic Resources, Freshwater Fisheries, Vejlsøvej 39, DK-8600 Silkeborg, Denmark.

3 Interdisciplinary Centre of Marine and Environmental Research (CIIMAR), University of Porto, Rua dos Bragas 289, 4050-123 Porto, Portugal.

* Corresponding author. Gerardo Antonio Cordero; Department of Ecology, Evolution, and Organismal Biology, Iowa State University, Ames, Iowa 50011 USA; E-mail: gcordero@iastate.edu

\begin{abstract}
Low-oxygen conditions (hypoxia; $<21 \% \mathrm{O}_{2}$ ) are considered unfavorable for growth; yet, embryos of many vertebrate taxa develop successfully in hypoxic subterranean environments. Though enhanced
\end{abstract}

This article has been accepted for publication and undergone full peer review but has not been through the copyediting, typesetting, pagination and proofreading process, which may lead to differences between this version and the Version of Record. Please cite this article as doi: 10.1111/1749-4877.12206.

This article is protected by copyright. All rights reserved. 
tolerance to hypoxia has been demonstrated in adult reptiles, such as in the painted turtle (Chrysemys picta), its effects on sensitive embryo life stages warrant attention. We tested the hypothesis that short-term hypoxia negatively affects growth during day 40 of development in C. picta, when $\mathrm{O}_{2}$ demands are highest in embryos. A brief, but severe, hypoxic event $\left(5 \% \mathrm{O}_{2}\right.$ for $\left.0.5 \mathrm{~h}\right)$ moderately affected embryo growth, causing a $13 \%$ reduction in mass (relative to a normoxic control). The same condition had no effect during day 27 ; instead a nearly anoxic event $\left(1 \% \mathrm{O}_{2}\right.$ for $\left.72 \mathrm{~h}\right)$ caused a $5 \%$ mass reduction. All embryos survived the egg incubation period. Our study supports the assumption that reptilian embryos are resilient to intermittently low $\mathrm{O}_{2}$ in subterranean nests. Further work is needed to ascertain responses to suboptimal $\mathrm{O}_{2}$ levels while undergoing dynamic changes in developmental physiology.

Key words: Embryo metabolism, growth rate, oxygen consumption rate, nest environment, embryo respiration.

\section{INTRODUCTION}

Organisms are perhaps most vulnerable to environmental unpredictability during embryonic life stages. In addition to moisture and temperature, fluctuations in oxygen $\left(\mathrm{O}_{2}\right)$ may influence normal development of vital organs, survival, and growth of vertebrate embryos (Kam and Lillywhite 1994;

This article is protected by copyright. All rights reserved. 
Fisher and Burggren 2007; Dunwoodie 2009; Liang et al. 2015; Lungman and Piña 2013; Smith et al. 2015). In oviparous tetrapods, embryo growth may be disrupted when gaseous $\mathrm{O}_{2}$ in the egg incubation environment decreases below normal atmospheric conditions $(<21 \%$; hypoxia hereafter) (Stock and Metcalfe 1987; Kam 1993a; Warburton et al. 1995; Dzialowski et al. 2002; Parker et al. 2004; Chan and Burggren 2005; Eme et al. 2013; Tate et al. 2015). Still, many tetrapods (e.g. megapode birds and non-avian reptiles) develop in subterranean nests that periodically experience hypoxia (Seymour and Ackerman 1980; Packard and Packard 1988; Booth and Thompson 1991; Booth 1998).

Available data from natural nests of non-avian reptiles (reptiles hereafter) indicate that $\mathrm{O}_{2}$ concentration may fluctuate between normoxic and hypoxic levels (10-21\%) (Thompson 1981; Booth and Thompson 1991; Booth 1998). Hypoxic conditions generally depend on biotic factors (e.g. embryo and microbial respiration, clutch size), as well as abiotic factors such as water saturation of soil (Packard and Packard 1988; Ackerman and Lott 2004; reviewed in Chen et al. 2010). The extent to which soil is saturated by water may determine the duration and severity of hypoxic conditions. For instance, severe hypoxic events are brief in natural turtle nests, lasting several hours after heavy rainfall (Booth 1998). Moreover, physical characteristics of soil, independent of water saturation, may contribute to hypoxia (Packard and Packard 1988; Ackerman and Lott 2004).

Physiological responses of reptilian embryos in subterranean nests vary according to developmental stage of cardiovascular and gas-exchange organs, which may exhibit increased efficiency in $\mathrm{O}_{2}$ transport during hypoxia (Kam 1993a; Corona and Warburton 2000; Crossley and Altimiras 2005). This form of developmental plasticity may enable normal $\mathrm{O}_{2}$ consumption during recurring hypoxic events (Kam 1993b). Furthermore, physiological sensitivity to hypoxia depends on the volume of $\mathrm{O}_{2}$ required to fuel rapid embryo growth during the last third of the egg incubation period, when the rate of embryo growth increases rapidly in vertebrates (Thompson 1989; Zonneveld and Kooijman 1993; Tullis and Peterson 2000). Consequently, reduction of growth rate is an evolutionarily conserved

This article is protected by copyright. All rights reserved. 
physiological response to hypoxia experienced late in embryonic development of vertebrates et al. 2005).

Late stages of embryonic development in turtles are particularly sensitive to hypoxia because high metabolic activity related to growth requires acceleration of $\mathrm{O}_{2}$ consumption rate (Ackerman 1981; Packard and Packard 1988; Tate et al. 2015). Hypoxia late in development may cause reduction of growth rate, as well as mortality, due to decreased $\mathrm{O}_{2}$ consumption in late-term embryos (Ackerman 1981; Kam 1993a; Kam 1994; Tucker et al. 1997; Eme et al. 2013; Tate et al. 2015). By contrast, enhanced tolerance to exceptional hypoxic conditions experienced seasonally in the adult life stage has been demonstrated in turtles that overwinter at high latitudes, such as the painted turtle (Emydidae: Chrysemys picta) (Bickler and Buck 2007; Jackson et al. 2007). Like other vertebrates, $C$. picta reaches peaks in rates of growth and $\mathrm{O}_{2}$ consumption during the last third of development (Lynn and Von Brand 1945; Peterson and Kruegl 2005). During this time, decreased $\mathrm{O}_{2}$ consumption due to hypoxia likely causes reduction of embryo growth, as demonstrated in other emydid turtles (e.g. Pseudemys nelsoni; Kam 1993a; Kam 1994).

The objective of the present study was to examine whether brief hypoxic events, as experienced in nature, have effects on embryo growth during sensitive windows of developmental physiology. Thus, we tested the hypothesis that embryo growth during day (d) 40 of development would be more sensitive to short-term hypoxia than during 27 d. Day 40 coincides with the expected peak in $\mathrm{O}_{2}$ consumption rate in C. picta (Peterson and Kruegl 2005).

\section{MATERIALS AND METHODS}

\section{Egg collection and incubation}

Clutches of eggs of $C$. picta bellii (western painted turtle; Figure 1) were collected from Beem near Hyannis, Nebraska, USA (described in Rowe 1994), on June 7-8, 2012 and June 12-13, 2013. Within 48 hours of oviposition, eggs were transported to Iowa State University, weighed, and

This article is protected by copyright. All rights reserved. 
half-buried in a moist vermiculite substrate (water potential $=-150 \mathrm{kPa}$ ) in plastic boxes with lids. Eggs were incubated in a single environmental chamber set to a constant $27^{\circ} \mathrm{C}$, which yields a $100 \%$ male sex ratio in C. picta (Etchberger et al. 1992). Egg boxes were rotated weekly to control for potential thermal gradients and vermiculite was rehydrated if needed. All boxes were treated identically, with the exception of hypoxic conditions described below.

\section{Experimental design}

Our experimental design resembled recently published methodology for inducing hypoxia during incubation of turtle eggs (Eme et al. 2013; Liang et al. 2015; Tate et al. 2015). Clutches of eggs collected in $2012(N=15$; mean clutch size: $5.9 \pm 0.63 \mathrm{SE})$ were randomly assigned to three treatments in Experiment 1: Normoxia control $\left(21 \% \mathrm{O}_{2}\right)$, hypoxia $\left(5 \% \mathrm{O}_{2}\right.$ for $\left.0.5 \mathrm{~h}\right)$ during stage 20 (St. 20_hypoxia; $27 \mathrm{~d}$ ), and hypoxia $\left(5 \% \mathrm{O}_{2}\right.$ for $\left.0.5 \mathrm{~h}\right)$ during early stage 22 (St. 22'_hypoxia; $\left.40 \mathrm{~d}\right)$. In Experiment 2, clutches of eggs collected in 2013 ( $N=6$; mean clutch size: 7.5 $\pm 1.7 \mathrm{SE})$ were randomly assigned to two treatments: Normoxia control $\left(21 \% \mathrm{O}_{2}\right)$, and hypoxia $\left(1 \% \mathrm{O}_{2}\right.$ for $\left.72 \mathrm{~h}\right)$ during stage 20 (St. 20_hypoxia; 27 d). Experiment 2 tested the prediction that $C$. picta embryos are more tolerant to hypoxia during stage 20 of Cordero and Janzen (2014).

\section{Rationale for treatments}

Fractional $\mathrm{O}_{2}$ concentrations of 1,5 , and $21 \%$ corresponded with partial pressures $\left(\mathrm{PO}_{2}\right) 7.36,36.8$, and 154.6 Torr. In natural nests of freshwater turtles, $\mathrm{PO}_{2}$ of $<100$ Torr $\left(<13 \% \mathrm{O}_{2}\right)$ lasting up to several days has been recorded following heavy rainfall (e.g. Chelodina expansa; Booth 1998). Also, flooding of nests likely causes extreme hypoxia (e.g. 1-5 \% $\left.\mathrm{O}_{2}\right)$ (Kam 1994; Tucker et al. 1997). Thus, our experimental treatments corresponded to field conditions. Similar laboratory manipulations elicited physiological responses in close taxonomic relatives of $C$. picta: Continuous hypoxia at 5\% $\mathrm{O}_{2}$ induced mortality in the closely related Trachemys scripta (Etchberger et al. 1991); brief hypoxia at $10 \% \mathrm{O}_{2}(0.5 \mathrm{~h})$ reduced heart rate (i.e. $\mathrm{O}_{2}$ transport) in Emys orbicularis (Nechaeva 2011); and

This article is protected by copyright. All rights reserved. 
hypoxia due to experimentally-induced flooding of nests lasting $72 \mathrm{hr}$ reduced rates of growth and $\mathrm{O}_{2}$ consumption in embryos of P. nelsoni (Kam 1994).

\section{Oxygen consumption rate}

Oxygen consumption rate $\left(\mathrm{V}_{2}\right)$ was measured using stop-flow respirometry. Eggs at St. 20 (27 d) and St. 22' (40 d) were placed individually in $500 \mathrm{~mL}$ glass jars with vermiculite substrate $(-150 \mathrm{kPa})$ held at a constant $27^{\circ} \mathrm{C}$. Each jar was flushed and then sealed for $90 \mathrm{~min}$. Air flow (500 mL/min) was then restored, water was scrubbed from air using Drierite desiccant, and $\mathrm{O}_{2}$ and carbon dioxide $\left(\mathrm{CO}_{2}\right)$ were measured using CA-10 and FC-10 analyzers, respectively (Sable Systems International). Oxygen consumption rate was calculated by integrating the change in instantaneous level over the period the jars were sealed, after correcting for barometric pressure and $\mathrm{CO}_{2}$, using ExpeData software (Sable Systems). This subset of eggs $(N=6)$ was excluded from other analyses.

\section{Oxygen manipulation}

A manually operated gas-mixing flow meter was used to gradually introduce nitrogen $\left(\mathrm{N}_{2}\right)$ gas to original egg boxes, now sealed with parafilm, until reaching targeted $\mathrm{O}_{2}$ concentrations, which were monitored in real time using fiber optic sensor technology (Fibox 3, PreSens Precision Sensing). This setup included a temperature-compensated oxygen sensor (Loligo Systems, Denmark) with $\mathrm{O}_{2}$ and temperature recorded by OxyView PST3-V5.32 software (PreSens Precision Sensing). Gases introduced to egg-containing boxes traveled through heat-exchanging coils that maintained temperature at $27{ }^{\circ} \mathrm{C}$. Eggs in experimental groups began incubation in $21 \% \mathrm{O}_{2}$ and were returned to that condition following hypoxic treatments. All egg boxes were weighed before and after experimental manipulation to ensure that water potential of egg substrate remained at $-150 \mathrm{kPa}$. Fractional $\mathrm{O}_{2}$ concentrations were corrected for barometric pressure, temperature, and water vapor.

This article is protected by copyright. All rights reserved. 
During normal incubation, we did not observe random deviation from normal atmospheric $\mathrm{O}_{2}(21 \%)$ in egg-containing boxes.

\section{Data collection}

Sampling in this study adhered to guidelines for animal care and use approved by ISU Institutional Care and Use Committee (protocol \# 2-11-7091-J). Euthanasia of embryos occurred in ovo via overnight fixation in $10 \%$ buffered formalin following standard protocol for preservation of reptilian embryos (Foster 2012). Eggs were fixed on 52 d (late stage 22), before yolk sac internalization (Mahmoud et al. 1973). To quantify stage-specific embryo mass, eggs incubated in normoxia were subsampled on 27 and 40 d. Fixed eggs were washed in distilled water to avoid tissue shrinkage (Stowell 1941). Embryos were then excised and residual yolk sacs (except in Experiment 2) and other extraembryonic tissues were discarded. Carapace length was measured to the nearest $0.1 \mathrm{~mm}$ along the anterior-posterior axis using digital calipers, following standard embryological methods for $C$. picta (Cordero and Janzen 2014). The anterior-posterior axis is mostly calcified and relatively undistorted by the flexible ellipse-shaped egg of emydids (Ewert 1985), thus it can be measured reliably at the end of egg incubation (e.g. Mahmoud et al. 1973; Packard et al. 1983; Cordero and Janzen 2014).

Yolk-free dry embryo mass, a more inclusive indicator of growth in embryonic turtles (Ewert 1985), was used to infer differences in energy allocated to production of tissue during development (Ar et al. 2004). Yolk-free embryos and separated yolk sacs (Experiment 2) were dried to a constant mass in an oven set to $60{ }^{\circ} \mathrm{C}$ for $72 \mathrm{~h}$. Yolk-free dry embryo mass and dry residual yolk mass (Experiment 2) were recorded to the nearest $0.001 \mathrm{~g}$ using an electronic balance. Embryo survival was inferred by examining external egg conditions (Ewert 1985), and egg pipping ( $\geq 1$ egg/group) was observed to determine completion of egg incubation because it is less variable than hatching time in

This article is protected by copyright. All rights reserved. 
C. picta (Gutzke et al. 1984). Egg pipping also indicates termination of the extended growth phase (stage 22; Cordero and Janzen 2014).

\section{Statistical analyses}

Maternal egg-energy investment (i.e., initial egg mass) can vary substantially among years in our study population (Rowe 1994). Therefore, data collected in 2012 (Experiment 1) and 2013 (Experiment 2) were analyzed separately. The effect of hypoxia on yolk-free dry embryo mass was tested using mixed-effect analysis of covariance (ANCOVA) with clutch of origin as a random factor and the following covariates: carapace length (Exps. 1 and 2), initial egg mass (Exps. 1 and 2), and dry residual yolk mass (Experiment 2 only). Carapace length and initial egg mass are strong predictors of wet hatchling mass in our study population (Rowe 1995). Initial egg mass controls for energetic maternal investment and carapace length for size.

Interaction terms, as well as initial egg mass and dry residual yolk mass, were excluded because they were not significant in preliminary models $(P$ 's $>0.18)$. Significant terms $(P<0.0001)$ for carapace length and initial egg mass (Experiment 1 only) were retained in final models. In all experimental groups, yolk-free dry embryo mass was normally distributed (Shapiro-Wilk's test, $P>$ 0.11). Tukey's HSD tests were used to evaluate mean differences among treatments. Covariate-adjusted means and their standard errors are reported. Analyses were conducted in the nlme package of the $\mathrm{R}$ programming language ( $\mathrm{R}$ Core Team 2014).

\section{RESULTS}

In Experiment 1, brief hypoxia $\left(0.5 \mathrm{~h}\right.$ at $\left.5 \% \mathrm{O}_{2}\right)$ had an effect on yolk-free dry embryo mass measured at the end of egg incubation (ANCOVA, $F_{2,55}=4.7034, P=0.013, N=74$ ), which was lower in the St. 22'_hypoxia (40 d; $N=24)$ treatment than in the St. 20_hypoxia (27 d; $N=26)$ and control groups (Figure 2A). This resulted in a 13\% mass reduction in St. 22'_hypoxia embryos, relative to the normoxic

This article is protected by copyright. All rights reserved. 
control $(N=24)$. Yolk-free dry embryo mass in the St. 20_hypoxia treatment did not differ from the control group (Figure 2A). In Experiment 2, severe hypoxia (72 h at 1\% $\mathrm{O}_{2}$ ) beginning on $27 \mathrm{~d}$ (St. 20_hypoxia; $N=14$ ) affected yolk-free dry embryo mass measured at the end of egg incubation (ANCOVA, $F_{1,19}=8.080, P=0.0104 ; N=27$ ) (Figure $2 \mathrm{~B}$ ). This resulted in a $5 \%$ mass reduction relative to the normoxic control $(N=13)$.

Yolk-free dry mass increased from $0.035 \mathrm{~g} \pm 0.001$ ( $27 \mathrm{~d}$, St. $20 ; N=5)$ to $0.177 \mathrm{~g} \pm 0.003$ (40 d, St. 22'; $N=5$ ) under normoxic incubation. Also, the rate of $\mathrm{O}_{2}$ consumption increased by more than two-fold: $\dot{\mathrm{V}}_{2}: 0.352 \mathrm{~mL} / \mathrm{hr} \pm 0.028(27 \mathrm{~d}$, St. $20 ; N=4)$ versus $\quad \dot{\mathrm{V}}_{2}: 0.859 \mathrm{~mL} / \mathrm{hr} \pm 0.032(40 \mathrm{~d}$, St. 22'; $N=6$ ). All embryos survived to the end of egg incubation: $\sim 52 \mathrm{~d}$ at $27{ }^{\circ} \mathrm{C}$. Means for initial egg mass, carapace length, and yolk-free dry embryo mass are reported in Table 1.

\section{DISCUSSION}

We report evidence of growth reduction in $C$. picta caused by short-term hypoxia in the egg incubation environment. Embryos briefly exposed to hypoxia on $40 \mathrm{~d}$, when high levels of $\mathrm{O}_{2}$ are required to fuel rapid growth, exhibited a decrease in yolk-free dry mass relative to embryos in normoxia. As expected, the same hypoxic treatment but earlier in development had little or no detectable effect on embryo mass. Notably, there was only a slight reduction in embryo growth after exposure to nearly anoxic conditions over $72 \mathrm{~h}$. In C. picta picta from New Jersey, $\mathrm{O}_{2}$ consumption rate increased by nearly two-fold from $27 \mathrm{~d}$ to $40 \mathrm{~d}$ (Peterson and Kruegl 2005). During this time frame, we demonstrated that $\mathrm{O}_{2}$ consumption rate increased by more than two-fold in C. picta bellii. Furthermore, estimates of embryo size and mass, as well as length of incubation were comparable to in C. picta bellii populations near our study site in Nebraska (Packard et al. 1983; Rowe 1995; reviewed in Cordero and Janzen 2014).

This article is protected by copyright. All rights reserved. 
Overall, our findings are biologically informative in revealing that: 1) brief, though severe, hypoxia is sufficient to reduce growth rate during a narrow window in development of C. picta; 2) reduction of growth rate is dependent on the timing and magnitude of hypoxia; 3) embryos of C. picta survive and possibly resume normal growth after experiencing exceptionally low $\mathrm{O}_{2}$. No prior experiment had subjected turtle embryos to such an extreme condition without placing eggs in substrate oversaturated with water (e.g. Kam 1994; Tucker et al. 1997).

\section{Resilience to hypoxia}

Survival of reptile embryos in subterranean nests is likely enabled by physiological adjustments that enhance $\mathrm{O}_{2}$ transport during hypoxic events, including hypervascularization and hypertrophy of gas-exchange organs (Kam 1993a; Corona and Warburton 2000; Crossley and Altimiras 2005; Nechaeva 2011). Although C. picta is remarkable in its capacity to withstand extreme hypoxic conditions experienced in the adult life stage (Bickler and Buck 2007; Jackson et al. 2007), our results do not suggest that tolerance to hypoxia during embryo life stages is exceptional relative to other turtles. When considering the duration of hypoxic conditions, the observed reduction in embryo growth was comparable to similar experiments on other turtles, which also did not detect effects on survival and length of incubation period (Kam '93b; Tucker et al. '97; Eme et al. 2013; Tate et al. 2015). However, survival and incubation period in turtles may be affected if temperature is suboptimal during hypoxia (Liang et al. 2015). Overall, our results corroborate that embryos in earlier stages of development are resilient to hypoxia.

\section{Narrow window of sensitivity to hypoxia?}

This article is protected by copyright. All rights reserved. 
Recent work has identified sensitive windows of physiological sensitivity to prolonged hypoxia $\left(10 \% \mathrm{O}_{2}\right.$ at up to $\left.636 \mathrm{~h}\right)$ that corresponded with alteration of cardiovascular function and decreased embryo growth in laboratory-incubated Snapping Turtles (Chelydridae: Chelydra serpentina; Tate et al. 2015). Both hypoxic time intervals in our study were brief $(0.5 \mathrm{~h}$ and $72 \mathrm{~h})$ and within the critical windows described for $C$. serpentina. However, the severity of hypoxia in our experiment was greater $\left(1 \%\right.$ or $5 \% \mathrm{O}_{2}$ ) and concurrent with the expected peaks in rates of $\mathrm{O}_{2}$ consumption and growth in $C$. picta (Lynn and Von Brand 1945; Packard et al. 1983; Peterson and Kruegl 2005). Our results suggest that critical windows of sensitivity to hypoxia are narrower, at least with respect to overall growth of embryos. Crucially, hypoxic events are brief in natural nests of freshwater turtles (Booth 1998).

\section{Ecological and evolutionary implications}

Reduction of embryo growth due to hypoxia is likely an evolutionarily conserved physiological response that increases the likelihood of survival when $\mathrm{O}_{2}$ available for respiration is limited (Kajimura et al. 2005). Accordingly, we showed that C. picta embryos with reduced mass caused by hypoxia survived the egg incubation period, as in other turtles (Etchberger et al. 1991; Kam 1993b; Eme et al. 2013; Tate et al. 2015). However, environmental fluctuation in subterranean nests of reptiles might affect fitness-related hatchling traits (Deeming 2004). In C. picta, hatchling size is considered a fitness-relevant trait because it is associated with increased likelihood of survival (Paitz et al. 2007). Therefore, whether physiological responses to hypoxia influence hatchling phenotypes, and potentially fitness, in $C$. picta needs to be addressed.

Eggs in natural nests of freshwater turtles likely experience brief hypoxia following heavy rainfall (Booth 1998). Although $\mathrm{O}_{2}$ data indicating hypoxia in natural nests of $C$. picta are not available, flooding of nests causes high embryo mortality (Christens and Bider 1987; Janzen 1994). This was

This article is protected by copyright. All rights reserved. 
supported by experiments that induced hypoxia by simulating flood events (Kam 1994; Tucker et al. 1997). Flooding also affects temperature and moisture, both of which exert combinatorial effects on metabolism of reptilian embryos (Kam and Lillywhite 1994; Lungman and Piña 2013; Liang et al. 2015; Smith et al. 2015).

Future studies should aim to examine multiple traits (e.g. heart rate and growth, hatchling phenotypes), as well as interactions of moisture, temperature, and $\mathrm{O}_{2}$ to comprehensively characterize how physiological systems respond to fluctuating $\mathrm{O}_{2}$ availability in subterranean nests. Still, our study is an important contribution towards illuminating effects of $\mathrm{O}_{2}$ limitation during particularly sensitive periods of embryonic development in vertebrate animals.

\section{REFERENCES}

Ackerman RA (1981). Oxygen consumption by sea turtle (Chelonia, Caretta) eggs during development. Physiological Zoology 54, 316-324.

Ackerman RA, Lott DB (2004). Thermal, hydric and respiratory climate of nests. In: Deeming D, edi. Reptilian Incubation: Environment, Evolution and Behaviour. Nottingham University Press, Nottingham, pp. 15-43.

Ar A, Belinsky A, Dmi'el R, Ackerman R (2004). Energy provision and utilisation. In: Deeming D, ed. Reptilian Incubation: Environment, Evolution and Behaviour. Nottingham University Press, Nottingham, pp. 143-185.

Bickler PE, Buck LT (2007). Hypoxia tolerance in reptiles, amphibians, and fishes: life with variable oxygen availability. Annual Review of Physiology 69, 145-170.

Booth D, Thompson M (1991). A comparison of reptilian eggs with those of megapode birds. In: Deeming D, Ferguson M, eds. Egg incubation: Its effects on embryonic development in birds and reptiles.

This article is protected by copyright. All rights reserved. 
Cambridge University Press, Cambridge, pp. 325-344.

Booth DT (1998). Nest temperature and respiratory gases during natural incubation in the broad-shelled river turtle, Chelodina expansa (Testudinata: Chelidae). Australian Journal of Zoology 46, 183-191.

Chan T, Burggren W (2005). Hypoxic incubation creates differential morphological effects during specific developmental critical windows in the embryo of the chicken (Gallus gallus). Respiratory Physiology and Neurobiology 145, 251-263.

Chen CL, Wang CC, Cheng IJ (2010). Effects of biotic and abiotic factors on the oxygen content of green sea turtle nests during embryogenesis. Journal of Comparative Physiology B 180, 1045-1055.

Christens E, Bider JR (1987). Nesting activity and hatching success of the painted turtle (Chrysemys picta marginata) in Southwestern Quebec. Herpetologica 43, 55-65.

Cordero GA, Janzen FJ (2014). An enhanced developmental staging table for the painted turtle, Chrysemys picta (Testudines: Emydidae). Journal of Morphology 275, 442-455.

Corona TB, Warburton SJ (2000). Regional hypoxia elicits regional changes in chorioallantoic membrane vascular density in alligator but not chicken embryos. Comparative Biochemistry and Physiology A 125, 57-61.

Crossley DA II, Altimiras J (2005). Cardiovascular development in embryos of the American alligator Alligator mississippiensis: effects of chronic and acute hypoxia. Journal of Experimental Biology 208, 31-39.

Deeming D (2004). Post-hatching phenotypic effects of incubation in reptiles. In: Deeming D, editor. Reptilian Incubation: Environment, Evolution and Behaviour. Nottingham University Press, Nottingham, pp. 229-251.

Dunwoodie SL (2009). The role of hypoxia in development of the mammalian embryo. Developmental Cell 17, 755-773.

This article is protected by copyright. All rights reserved. 
Dzialowski EM, von Plettenberg D, Elmonoufy NA, Burggren WW (2002). Chronic hypoxia alters the physiological and morphological trajectories of developing chicken embryos. Comparative Biochemistry and Physiology A 131, 713-724.

Eme J, Rhen T, Tate KB, Gruchalla K, Kohl ZF, Slay CE, Crossley DA II (2013). Plasticity of cardiovascular function in snapping turtle embryos (Chelydra serpentina): chronic hypoxia alters autonomic regulation and gene expression. American Journal of Physiology Regulation, Integration, and Comparative Physiology 304, R966-R979.

Etchberger CR, Phillips JB, Ewert MA, Nelson CE, Prange HD (1991). Effects of oxygen concentration and clutch on sex determination and physiology in red-eared slider turtles (Trachemys scripta). Journal of Experimental Zoology 258, 394-403.

Etchberger CR, Ewert MA, Raper BA, Nelson CE (1992). Do low incubation temperatures yield females in painted turtles? Canadian Journal of Zoology 70, 391-394.

Ewert MA (1985). Embryology of turtles. In Gans C, Billet F, Maderson PFA, eds. Biology of the Reptilia. John Wiley \& Sons, Inc., pp. 75-267.

Fisher SA, Burggren WW (2007). Role of hypoxia in the evolution and development of the cardiovascular system. Antioxidants \& Redox Signaling 9, 1339-5132.

Foster MS (2012). Preparing reptiles as voucher specimens. In McDiarmid RW, Foster MS, Guyer C, Gibbons JW, Chernoff N, eds. Reptile Biodiversity: Standard Methods for Inventory and Monitoring. University of California Press, Berkeley, pp. 95-126.

Gutzke HN, Paukstis GL, Packard GC (1984). Pipping versus hatching as indices of time of incubation in reptiles. Journal of Herpetology 18, 494-496.

Jackson DC, Taylor SE, Asare V, Villarnovo D, Gall J, Reese SA (2007). Comparative shell buffering properties correlate with anoxia tolerance in freshwater turtles. American Journal of Physiology - Regulation, Integration, and Comparative Physiology 292, R1008-R1015.

Janzen FJ (1994). Climate change and temperature-dependent sex determination in reptiles.

This article is protected by copyright. All rights reserved. 
Proceedings of the National Academy of Science 91, 7487-7490.

Kajimura S, Aida K, Duan C (2005). Insulin-like growth factor-binding protein-1 (IGFBP-1)

mediates hypoxia-induced embryonic growth and developmental retardation. Proceedings of the National Academy of Science 102, 1240-1245.

Kam Y-C (1993a). Physiological effects of hypoxia on metabolism and growth of turtle embryos. Respiratory Physiology 92, 127-138.

Kam Y-C (1993b). Critical oxygen tension of reptilian embryos. Comparative Biochemistry and Physiology 105A, 777-783.

Kam Y-C (1994). Effects of simulated flooding on metabolism and water balance of turtle eggs and embryos. Journal of Herpetology 28, 173-178.

Kam, Y-C, Lillywhite HB (1994). Effects of temperature and water on critical oxygen tension of turtle embryos. Journal of Experimental Zoology A 268, 1-8.

Liang L, Sun BJ, Ma L, Du WG (2015). Oxygen-dependent heat tolerance and developmental plasticity in turtle embryos. Journal of Comparative Physiology B 185, 257-263.

Lungman JL, Piña CI (2013). Hypoxia and temperature: Does hypoxia affect caiman embryo differentiation rate or rate of growth only? Journal of Thermal Biology 38, 407-418.

Lynn W, Von Brand T (1945). Studies on the oxygen consumption and water metabolism of turtle embryos. Biological Bulletin 88, 112-125.

Mahmoud I, Hess GL, Klicka J (1973). Normal embryonic stages of the western painted turtle, Chrysemys picta bellii. Journal of Morphology 141, 269-280.

Nechaeva MV (2011). Physiological responses to acute changes in temperature and oxygenation in bird and reptile embryos. Respiratory Physiology \& Neurobiology 178, 108-117.

Packard GC, Packard MJ, Boardman TJ, Morris KA, Shuman RD (1983). Influence of water exchanges by flexible-shelled eggs of painted turtles Chrysemys picta on metabolism and

This article is protected by copyright. All rights reserved. 
growth of embryos. Physiological Zoology 56, 217-230.

Packard GC, Packard MJ (1988). The physiological ecology of reptilian eggs and embryos. In Gans C, Huey R, eds. Biology of the Reptilia. Alan R. Liss, Inc., New York, pp 524-605.

Paitz RT, Harms HK, Bowden RM, Janzen FJ (2007). Experience pays: offspring survival increases with female age. Biology Letters 3, 44-46.

Parker S, Andrews R, Mathies T (2004). Embryonic responses to variation in oviductal oxygen in the lizard Sceloporus undulatus from New Jersey and South Carolina, USA. Biological Journal of the Linnean Society 83, 289-299.

Peterson C, Kruegl A (2005). Peaked temporal pattern of embryonic metabolism in an emydid turtle (Chrysemys picta picta). Journal of Herpetology 39, 678-681.

R Core Team (2014). R: A language and environment for statistical computing. R Foundation for Statistical Computing, Vienna, Austria. URL http://www.R-project.org/.

Rowe JW (1994). Reproductive variation and the egg size-clutch size trade-off within and among populations of painted turtles (Chrysemys picta bellii). Oecologia 99, 35-44.

Rowe JW (1995). Hatchling size in the turtle Chrysemys picta bellii from western Nebraska: relationships to egg and maternal size. Journal of Herpetology 29, 73-79.

Seymour RS, Ackerman RA (1980). Adaptations to underground nesting in birds and reptiles. American Zoologist 1980, 437-447.

Smith C, Telemeco RS, Angilletta MJ, Jr., VandenBrooks JM (2015). Oxygen supply limits the heat tolerance of lizard embryos. Biology Letters 11, 20150113.

Stock MK, Metcalfe J (1987). Modulation of growth and metabolism of the chick embryo by a brief (72-hr) change in oxygen availability. Journal of Experimental Zoology, supplement 1, $351-356$.

Stowell RE (1941). Effect on tissue volume of various methods of fixation, dehydration, and embedding. Biotechnic \& Histochemistry 16, 67-83.

This article is protected by copyright. All rights reserved. 
Tate KB, Kohl ZF, Eme J, Rhen T, Crossley DA II (2015). Critical windows of cardiovascular susceptibility to developmental hypoxia in common snapping turtle (Chelydra serpentina) embryos. Physiological and Biochemical Zoology 88,103-115.

Thompson MB (1981). Gas tensions in natural nests and eggs of the tortoise Emydura macquarii. In: Banks CB, Martin AA, eds. Proceedings of the melbourne herpetological symposium. Zoological Board of Victoria, Parkville, Australia, pp. 74-77.

Thompson MB (1989). Patterns of metabolism in embryonic reptiles. Respiratory Physiology 1989, 243-256.

Tucker JK, Janzen FJ, Paukstis GL (1997). Response of embryos of the red-eared turtle (Trachemys scripta elegans) to experimental exposure to water-saturated substrates. Chelonian Conservation and Biology 2, 345-351.

Tullis A, Peterson G (2000). Growth and metabolism in the embryonic white-spotted bamboo shark, Chiloscyllium plagiosum: comparison with embryonic birds and reptiles. Physiological and Biochemical Zoology 73, 271-282.

Warburton SJ, Hastings D, Wang T (1995). Responses to chronic hypoxia in embryonic alligators. Journal of Experimental Zoology 273, 44-50.

Zonneveld C, Kooijman SA (1993). Comparative kinetics of embryo development. Bulletin of Mathematical Biology 55, 609-635.

This article is protected by copyright. All rights reserved. 
Table 1. Means of yolk-free dry embryo mass and carapace length (measured at the end of egg incubation; $52 \mathrm{~d}$ at $27^{\circ} \mathrm{C}$ ), as well as initial egg mass in Chrysemys picta bellii.

\begin{tabular}{lccc}
\hline Group & $\begin{array}{c}\text { Initial egg mass } \\
(\mathrm{g} \pm \mathrm{SE})\end{array}$ & $\begin{array}{c}\text { Yolk-free dry } \\
\text { embryo mass }(\mathrm{g} \\
\pm \mathrm{SE})\end{array}$ & $\begin{array}{c}\text { Carapace length } \\
(\mathrm{mm} \pm \mathrm{SE})\end{array}$ \\
\hline Experiment $1^{+}$ & $5.48 \pm 0.154$ & $0.615 \pm 0.034$ & $21.6 \pm 0.30$ \\
Control & $5.56 \pm 0.172$ & $0.612 \pm 0.020$ & $21.9 \pm 0.29$ \\
St. 20_hypoxia & $5.53 \pm 0.121$ & $0.535 \pm 0.022$ & $22.4 \pm 0.24$ \\
St. 22'_hypoxia & & & \\
Experiment $2^{+}$ & $6.91 \pm 0.116$ & $0.671 \pm 0.012$ & $22.9 \pm 0.24$ \\
Control & $7.01 \pm 0.134$ & $0.640 \pm 0.011$ & $23.3 \pm 0.20$ \\
St. 20_hypoxia & & &
\end{tabular}

$+=\mathrm{In}$ Experiment 1: hypoxia was set to $5 \% \mathrm{O}_{2}$ for $0.5 \mathrm{~h}$ on $27 \mathrm{~d}$ (stage [St.] 20) and $40 \mathrm{~d}$ (St. 22'); in

Experiment 2, hypoxia was set to $1 \% \mathrm{O}_{2}$ for $72 \mathrm{~h}$ on $27 \mathrm{~d}$ (St. 20). Control: constant $21 \% \mathrm{O}_{2}$

Figure 1 Hatchling Chrysemys picta bellii after emergence from its subterranean nest.

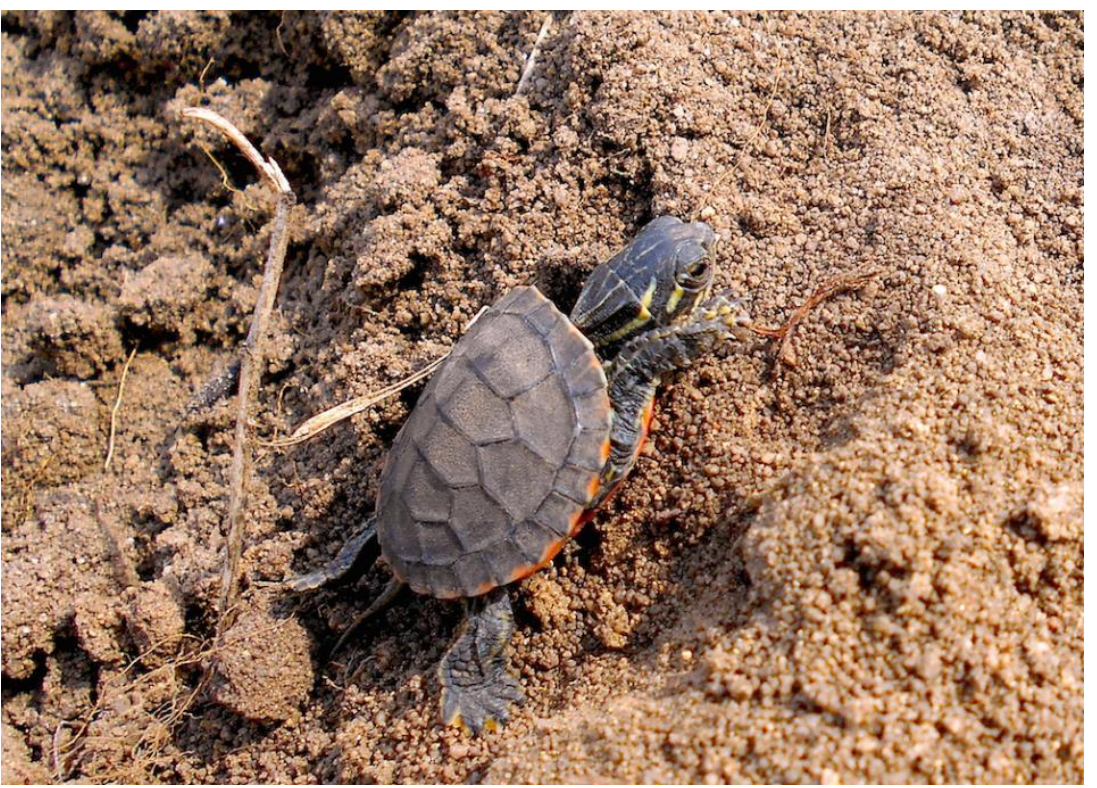

This article is protected by copyright. All rights reserved. 
Figure 2 Means $( \pm$ SE) of yolk-free dry embryo mass (adjusted for carapace length and initial egg mass) in Chrysemys picta bellii differed only in control $\left(21 \% \mathrm{O}_{2}\right)$ versus the St. 22' hypoxia $\left(5 \% \mathrm{O}_{2}\right.$; 40 d) groups (A; Experiment 1). In Experiment 2 (B), covariate-adjusted means of the control (21\% $\left.\mathrm{O}_{2}\right)$ and St. 20_hypoxia $\left(1 \% \mathrm{O}_{2} ; 27\right.$ d) groups differed. Yolk-free dry embryo mass and carapace length were recorded at the end of egg incubation $\left(\sim 52 \mathrm{~d}\right.$ at $\left.27^{\circ} \mathrm{C}\right) ; *=$ statistically significant mean difference $(P<0.05)$.

This article is protected by copyright. All rights reserved. 

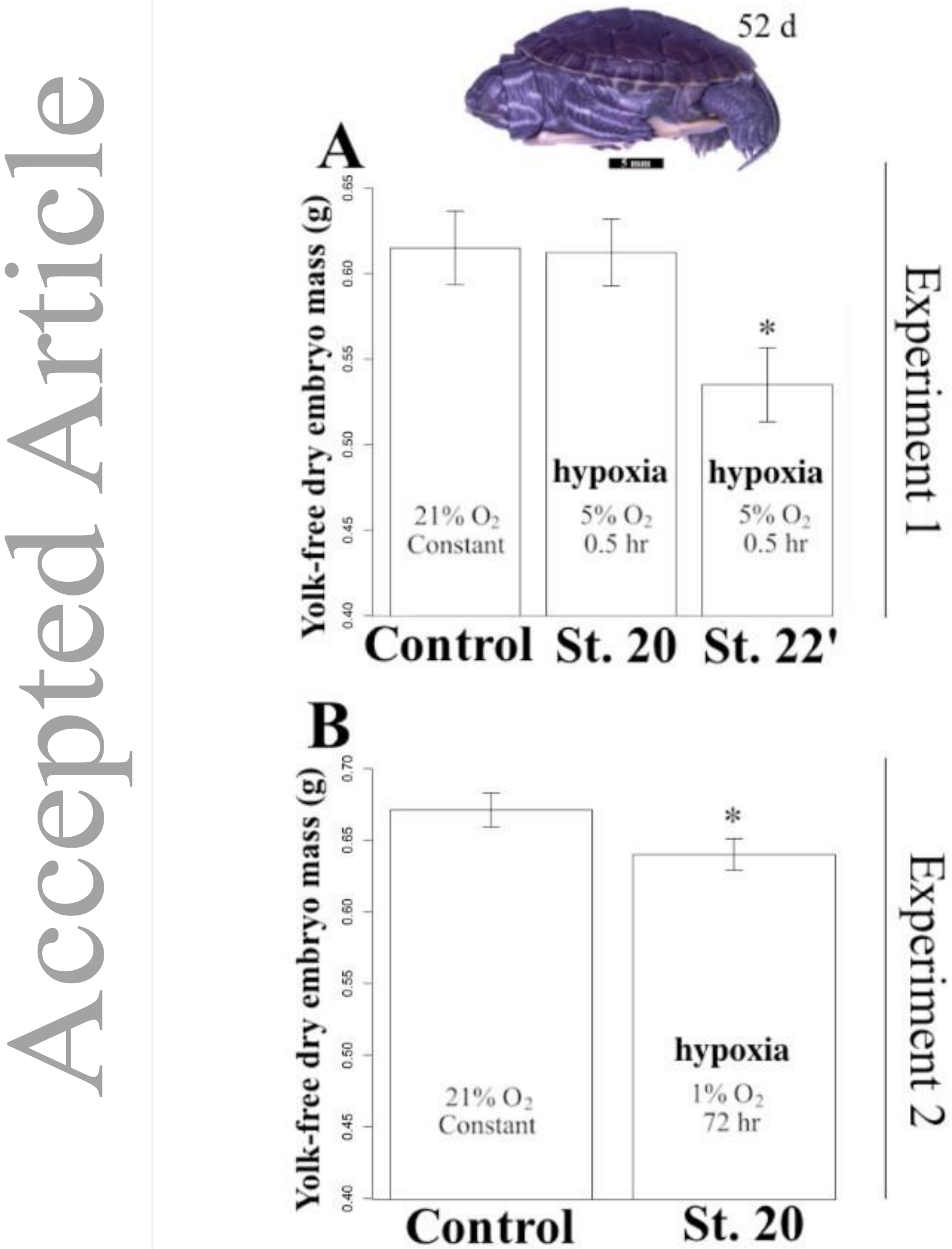